\title{
Teaching the Bible at public universities in South Africa: A proposal for multidisciplinary approach
}

\begin{tabular}{|c|c|}
\hline \multicolumn{2}{|c|}{$\begin{array}{l}\text { Author: } \\
\text { Zorodzai Dube }{ }^{1}\end{array}$} \\
\hline $\begin{array}{l}\text { Affiliation: } \\
{ }^{1} \text { Department o } \\
\text { Testament Stu } \\
\text { University of P } \\
\text { South Africa }\end{array}$ & $\begin{array}{l}\text { f New } \\
\text { dies, } \\
\text { retoria, }\end{array}$ \\
\hline $\begin{array}{l}\text { Note: } \\
\text { Dr Zorodzai Du } \\
\text { post-doctoral f } \\
\text { the vice-chanc } \\
\text { the University } \\
\text { and is participa } \\
\text { research fellov } \\
\text { Dr Gert J. Stey } \\
\text { the Departmer } \\
\text { Testament Stu } \\
\text { Faculty of The } \\
\text { the University } \\
\text { Pretoria, South }\end{array}$ & $\begin{array}{l}\text { Abe is a } \\
\text { fellow of } \\
\text { ellor of } \\
\text { of Pretoria } \\
\text { ating as a } \\
N \text { of Prof. } \\
n \text {, head of } \\
\text { nt of New } \\
\text { dies of the } \\
\text { ology at } \\
\text { of Pretoria, } \\
h \text { Africa. }\end{array}$ \\
\hline $\begin{array}{l}\text { Corresponden } \\
\text { Zorodzai Dube }\end{array}$ & Ice to: \\
\hline $\begin{array}{l}\text { Email: } \\
\text { dubez@unisa. }\end{array}$ & ac.za \\
\hline $\begin{array}{l}\text { Postal address } \\
\text { University of S } \\
\text { 4-8 Samuel Pa } \\
\text { Muckleneuk, P } \\
\text { South Africa }\end{array}$ & $\begin{array}{l}\text { outh Africa, } \\
\text { retoria 0081, }\end{array}$ \\
\hline $\begin{array}{l}\text { Dates: } \\
\text { Received: } 03 \mathrm{~J} \\
\text { Accepted: } 17 \mathrm{~J} \\
\text { Published: } 02 \mathrm{I}\end{array}$ & $\begin{array}{l}\text { uly } 2012 \\
\text { lan. } 2013 \\
\text { May } 2013\end{array}$ \\
\hline $\begin{array}{l}\text { How to cite th } \\
\text { Dube, Z., } 2013 \\
\text { Bible at public } \\
\text { South Africa: } \\
\text { multidisciplina } \\
\text { HTS Teologiese } \\
\text { Theological Stu } \\
\text { Art. \#1295, } 6 \text { p } \\
\text { http://dx.doi.o } \\
\text { hts.v69i1.1295 }\end{array}$ & $\begin{array}{l}\text { is article: } \\
\text {, 'Teaching the } \\
\text { universities in } \\
\text { A proposal for } \\
\text { ry approach', } \\
\text { e Studies/ } \\
\text { udies 69(1), } \\
\text { oages. } \\
\text { org/10.4102/ }\end{array}$ \\
\hline $\begin{array}{l}\text { Copyright: } \\
\text { C 2013. The A } \\
\text { Licensee: AOSI } \\
\text { OpenJournals. } \\
\text { is licensed und } \\
\text { Creative Comn } \\
\text { Attribution Lice }\end{array}$ & $\begin{array}{l}\text { Iuthors. } \\
\text { IS } \\
\text { This work } \\
\text { der the } \\
\text { nons } \\
\text { ense. }\end{array}$ \\
\hline Read online: & $\begin{array}{l}\text { Scan this QR } \\
\text { code with your } \\
\text { smart phone or } \\
\text { mobile device } \\
\text { to read online. }\end{array}$ \\
\hline
\end{tabular}

How should the academy teach the Bible? I noted two challenges to this endeavour. Firstly, the Bible has been used as superstructure to justify and to solidify colonialism and apartheid in South Africa which resulted in people to mistrust the way the Western missionaries interpreted the Bible. It also gave birth to the inception of African Independent Churches (AIC) and an urgent need to reinterpret the Bible from the experiences of Africans. However, the initial question remains how the academy should teach the Bible. The complexity of this question is that despite the Bible's association with a colonial legacy, the ordinary people did not stop reading the Bible and to make meaning of their lives from it. This study justifies the place of the Bible in public universities in South Africa and proposes ways the academy should teach the Bible. This study suggests a two-pronged approach to Biblical Studies at public universities. Firstly, the academy should critically engage the ideological presupposition underlying the theories used in the academy. Secondly, the academy must be open to the fact that the Bible is part of popular culture; hence, the academy should critically reflect how the Bible is used in public space. Therefore my hypothesis is that the academy should further focus on critiquing ideological inclinations that underline established truths in addition to focusing on the historical meaning of the Bible and establishing contextual similarities. Teaching the Bible should focus on analysing cultural, political and economic ideological truths that find support from the Bible. I propose that this line of thought is possible through cultural studies and/or interdisciplinary methods.

\section{Introduction}

The title of this study developed from the seminar held by the Department of New Testament at the University of South Africa, which was entitled: 'How to Teach the Bible at Public Universities in South Africa'. The seminar explored various ways through which the academy teaches the Bible at public universities in South Africa. Historically, the Bible claims its rightful place in the academy since the medieval period with the establishment of monasteries and universities. Back then, theology was amongst the main subjects taught at universities. The seminar at the University of South Africa was organised because of the following observations, namely, (1) a realisation that the shift from a colonial era to independence demands a set of new hermeneutical tools to interpret the Bible; (2) there are low student numbers in the departments that offer Theology or Biblical studies due to the perceptions that such subjects have less relevance to the community; and (3) some universities in South Africa opted not to offer theology or biblically related subjects. Given this reality, the seminar grappled with the following question: Should the Bible be taught at public universities in South Africa? If yes, what expertises are expected from graduates in Theology or Biblical Studies?

To me, these questions are not distant given that many times I find myself in a position where I must explain my profession as a biblical scholar, a situation that graduates in Engineering or in Medical Science might not face. Recently, I had to explain to the Ministry of Home Affairs how my training as a biblical scholar amounts to exceptional skills that the country needs. My personal question to this study is why should graduates in Biblical Studies need to explain their training? In this study I argue that the confusion seemingly resides in how the Bible is taught, that is, in the approaches or methods used in biblical studies. The question is what theories are needed for teaching the Bible and how do we make sure that we produce students who are competent and marketable within their society.

\section{Are traditional Western approaches effective methods in Africa?}

From the onset, we face the challenge concerning which methods to use. Seemingly, departments that teach biblical studies adopt new methods at a snail's pace. The academy needs methods or theories to achieve desired goals and theories should be critically evaluated in view of aimed 
objectives. Madipoane Masenya (2004:455) exposed the above dilemma in an article: Teaching Western-oriented Old Testament Studies to African students: An exercise in wisdom or in folly. In the article, Masenya bemoans the continuous use of Western methods in biblical studies. I am not suggesting that the end of colonialism and apartheid signalled the end of everything associated with the West. Instead, I agree with Masenya that Western methods continue to alienate Africa, since they raise Western questions and issues. According to Masenya (2004:457), the continuous use of Western methods perpetuates the alienation of Africa from biblical discourse and from raising her own existential questions. She berated the way Western biblical methods thrive on sophisticated arguments which have no bearing on the daily lives of the people. Masenya illustrated this through an African proverb that says the 'artificial horns that are placed on the head of a hare, do not stick', which simply means a method that works in one context should not be imposed on another context. According to Masenya (2004:457), there is a need to interpret the Bible in view of African social realities. A biblical curriculum for Africa would be one that takes the realities of Africa seriously.

The Eurocentric bias and prescriptive nature of methods used is apparent in theories that are used in biblical studies such as historical, cultural, literary and cultural criticism. These theories stand accused of being Eurocentric in their world view (Segovia 1998b:1). American scholar, Fernando Segovia indicts historical criticism for (1) making learners passive recipients of information by demanding learners acquire the right methodological tools, thereby converting them into universal critics; (2) the method is pyramidal, authoritative and patriarchal; and (3) it is also accused of dehumanisation since the learners must learn the tools, that is, knowledge of the period and area under study, original language and historical background of the text (Segovia 1998b:3). The rigorous task aims to make the leaner grasp the original meaning of the text intended by the author. Segovia further castigates a historical critical method saying it is a pedagogical model that is highly pyramidal, patriarchal and authoritative, a model where the teacher is the voice of reason, and he or she alone collects and disseminates the historical mysteries of the text as ancient record to the students. The theory supposes that the teacher rise above his or her social location and ideology to arrive at the objective and unbiased meaning of the text (Segovia 1998b:3).

Similarly, literary criticism is accused of demanding the learners to acquire the methodological tools as prerequisite for right interpretation; hence it also remains pyramidal and authoritative. By claiming that the learners should thrive to know the meaning created by the real readers, the method reifies the meaning from the every reader (Segovia 1998a:4).

In addition, the cultural theory method shares traits found in the historical critical method, that of: regarding the learners as passive recipients who must know the social system and cultural history behind the text. Cultural theory, a method that seeks to know the ancient culture of the Mediterranean world must be distinguished from cultural studies, which is a new interdisciplinary method. Through cultural studies, students must familiarise themselves with concepts in cultural anthropology, especially those that relate to the ancient Mediterranean society. By putting emphasis on learnt impartation, the model is likewise pyramidal and authoritative, patriarchal to the core.

Given this, African scholars such as Masenya assert that biblical studies are profoundly Eurocentric or Western. Such Eurocentrism matches the patriarchal nature of the discipline and reflects not only the broader Eurocentric character of theological education in general but also the strong Eurocentric control over other cultures. Segovia concurs saying biblical studies at Universities is characterised by:

- confinement of the task of interpretation to the past

- focus on the discovery of the original meaning of the text, the meaning back then

- emphasis on the impartation and absorption of information

- insistence on a particular method or cultural understanding

- emphasis on Christological and stereological questions, such as the issue of religious salvation

- an erroneous belief that the method must be universally applied, which results in the exaltation of Western epistemologies, thereby excluding other cultures and world views as inadequate, which results in other cultures to conform to the traditions and dictates of the normative positions (Segovia 1998b:7).

In my view, the shift of the centre of Christianity from the West to the South and the subsequent advent of postmodernism with its emphasis on relativity of truth, multiple contexts, cultures and experiences, render traditional approaches to the Bible redundant. I suppose the slow change in methods might be attributed to several reasons, namely, (1) lack of interdisciplinary engagement; and (2) fear of losing cherished identities by departments. I am not suggesting that everything that the above methods stood for was bad, but rather, I argue that studying the Bible in a historical context does not always serve the immediate needs of the readers, which is the focus of methods that emphasise the importance of the reader's context.

\section{The context is key}

The lack of engagement with the experiences of the readers creates polarity between the academy and the untrained readers. Each day people glean subjective meanings from the Bible and view those according to their own circumstances. This echoes the anecdote that when the missionaries came they had the Bible and the Africans had their land. The missionaries said, 'let us close our eyes and pray' and after the prayer, the missionaries had the land and the Africans had the Bible (Mafokeng 1988:34). This anecdote shows how the missionaries played a part in aiding colonialism and Western capitalism. True as it is, yet on the other hand, the saying emphasises the pervasiveness of biblical knowledge amongst Africans. Despite the ugly history associated with the Bible, the Africans cling to the Bible as their own book. One can say that the Bible is at home in Africa, which is evidenced by the growth of the church throughout the continent. Today, 
Africa and South Africa in particular is the home to various churches. These include the mainline churches that were planted by the missionaries and an uncountable number of African-initiated churches, in addition to various Pentecostal churches. It is not an exaggeration to say that the Bible is stirring and is alive in communities, which is evidenced by daily Bible meetings, Sunday church services, and various church fellowships.

Traditionally, the academy would label the way the communities interpret the Bible as eisegesis because ordinary readers lack scientific methods. The academy was slow to compliment what the ordinary people are doing with the Bible. In my view, the academy's slow metamorphosis can be attributed to Western scholars' strong grip on university curricula, which resulted in the academy to continue using Western-oriented methods with little to report on the reader's social reality.

In retrospect, the response by the academy was gradual and it came in three forms: one way was to compliment grassroots interpretations by rebutting Western epistemology. On a general platform, this paradigm characterises approaches such as postcolonial approaches to the Bible and African philosophy. Postcolonialism stems from the need to expose hegemonic imposition of meaning by the colonial masters over the ordinary people. It also seeks to explore various ways in which the ordinary people subvert prescribed meaning by coming up with their own meaning, thus re-narrating history from the perspective of the oppressed. This is also true of African philosophy that sought to hail African epistemologies which for a long period were silenced and seen as uncouth and primitive in comparison to Western thinking.

Responses that were specific to biblical studies came from African biblical scholars who voiced the need for contextual interpretation of the Bible. For example John Mbiti and V. Mugambi sought to correlate African culture with the biblical world (Kabasela 1997). Other biblical scholars emphasised the similarity between the African customs, values, world view and beliefs as key to biblical interpretation. Recently, a South African scholar, Madipoane Masenya (2004:469) voiced the need to tap African proverbs as key to African hermeneutics. Similarly, South African scholars such as Takatso Mofokeng, Allan Boesak, Bonganjalo Goba and Simon Maimela searched for shared experiences as basis to interpret the Bible. Gerald West (West 2000:30) and Tinyiko Maluleke (Maluleke 2000:98) also gave us glimpses regarding how the African interpreted the Bible saying that the Africans negotiated and transacted with the Bible 'appropriating, relativising it and finding existential meaning to their situations.' Their experiences of race, culture, gender and class influenced how they read the Bible (West 1993:12).

The advantage of a contextual approach is the serious consideration of the social context of the readers as basis to create meaning from the Bible. Unlike historical methods that confine the meaning of the Bible to the past, contextual approaches consider the transaction between the experiences of the readers and the Bible as a locus for meaning. Through a contextual approach, readers re-contextualise Bible images and stories within their own cultures and contexts, such that events in the Bible are seen as a mirror of their own experiences.

In my view, both the Western traditional approaches and the contextual perspectives should be used as foundational approaches. My argument is based on the fact that (1) postmodernity cut the exclusive right to meaning, which suggests that interpretation should not be based on particular theories to be regarded as true; and (2) interdisciplinary interaction with other disciplines in the Faculty of Human Sciences should broaden the tools for presenting biblical studies. My argument is that biblical studies should not be only about the search for historical truth regarding the ancient Mediterranean societies; neither should it only focus on contextual methods between the world of the Bible and the present. Instead, it should focus on how truths about both the past and the present are galvanised through use of the Bible. Building upon this perspective, this means that biblical interpretation is an ideological and political contest. Reconstruction of the biblical world using archaeology, anthropology or other methods serve as an implicit reconstruction of our own ideologies, agenda and histories and are not an objective undertaking. Hence, biblical studies should move from asking the question what happened in the past to asking how past events are reinterpreted in view of our own idiosyncrasies. Instead of asking how the Exodus event happened, we should ask how those who are suffering use the Exodus event as ideology to establish collective identities. How is the Bible used as ideology to claim the right of the present nation of Israel to exist as a nation? How is the Bible used as ideology to deny gay rights? How is it used as ideology to justify a patriarchal family structure? This perspective is possible through use of a multidisciplinary approach or cultural studies.

\section{A proposal for multidisciplinary approach to Biblical Studies}

The strength of my study is by proposing the use of cultural studies or an interdisciplinary approach to study the Bible at public universities. I used interdisciplinary interchangeably with cultural studies because cultural studies 'does not speak with one voice, it cannot be spoken with one voice, and I do not have one voice with which to represent it.' Cultural studies constitute a multidisciplinary field of enquiry which blurs the boundaries between itself and other subjects. It draws upon various fields. It is concerned with matters of power and politics by:

exploration of representation of and for marginalised social groups and the need for cultural change. Hence Cultural studies is a body of theory generated by thinkers who regard the production of theoretical knowledge as a political practice. (Baker 2008:5)

It assumes that knowledge is 'never a neutral or objective phenomenon but a matter of positionality that is, of the place from which one speaks, to whom and for what purpose' (Baker 2008:5). 
Using cultural studies as basis for the discussion, we ask: What is the core business of biblical studies? I must reiterate that use of cultural studies does not obliterate the traditional Western and the contextual approaches, but instead, it seeks to strengthen the way Bible studies are rendered by further inquiring how the Bible is part of creating identities and solidifying certain perceptions or truth claims. When using cultural studies, emphasis should be placed on how power is maintained and gained through particular meanings. This means that biblical interpretation is not an innocent search for meaning, or a purely illuminated knowledge about the past, but instead, it unravels how interpretation is intertwined with ideology and power.

Let me illustrate using the view of Michel Foucault (1980:133) to show how biblical interpretation is intertwined with power and ideology. Foucault discusses how the government controls people through use of the army, police and actions such as surveillances. He also noted that centres of knowledge such as universities and psychiatric institutions function to delimit people's freedom and knowledge. For him, universities and colleges are centres of knowledge in the society. Yet, the academy can also be centres that stifle knowledge and alienate truth. Foucault illustrates this point by saying that educational institutions function to produce 'truth', which is not neutral, instead, 'truth is linked in a circular relation with systems of power which produces and sustains it, and to effects of power which it induces and which extend it' (Foucault 1980:133). I greatly value Foucault's perspective because it supports the argument of this article. In simple terms, theories are not neutral; instead, they are used to channel people's views and perceptions, thus making people to think in a certain way. Using the methods and the theories, the academy implicitly produces scholars who are receptive to particular ideologies.

This does not only apply to the academy, but also to the communities in the manner in which patriarchal positions are solidified and sustained using the Bible. In various churches, though women register higher attendance, but the few men who attend the church service are given church leadership positions. To justify such practices, for example, the biblical passages that say that man was created first and then a woman, are used to justify men's patriarchal ideology. Other passages that are frequently used are those that say that Jesus is the head of the church and a man is the head of the family.

To delimit the scope of the article, it would be a folly to attempt to exhaust all areas that could be discussed. I therefore round up by illustrating how cultural studies can be used to refocus biblical studies at public universities. The following below are my suggested proposals.

The subject of Biblical Studies at public universities should use views from sociology and psychology to raise issues about how the Bible is used to establish individual and collective identities. As Segovia (1998a:4) noted, the biblical text should be viewed as literary text or artistic products, rhetorical and strategic products and cultural or ideological products. In my view this means that when people read the Bible they are less interested in the historical context of the Bible, than with what it means to their lives. In this case biblical studies, using cultural studies should investigate the social realities affecting people and how the Bible is used as a central tool in meaning making. In communities the Bible is not regarded as a historical book, but rather, it is a living book, which is vibrant and living in people's lives. As a result, churches and church camps and fellowship groups are attended in great numbers by people. Theories in psychology and sociology will complement theories already used in biblical departments to further investigate, sociologically, why the Bible is such a central book in people's lives.

The subject of Biblical Studies at public universities should incorporate views from media studies to investigate the appropriation and deployment of biblical motifs, scenes, situations and themes in diverse fields such as art, films, music. This means that the Bible is not only a religious book but also that it's meaning is a cultural product. It should raise questions such as: How is religion incorporated in films, art and music? For example, during the height of political violence in Zimbabwe, the national television and radio played more religious songs compared to other songs. This was evidenced by the fact that during the annual Zimbabwe Music Awards (ZIMA), gospel musicians scooped more awards compared to their compatriots; and in most Nigerian movies religious themes are emphasised. A common and predictable theme in Nigerian movies is where an actor in the movie faces challenges in life, and he or she tries various solutions but to no avail and finally he or she goes to church and events tilt in his or her favour. This can also be traced in other African movies where the church is projected as a place of refuge and personal fortunes. Using cultural studies, biblical studies have a fertile ground to explore how religion is projected in movies and art.

The subject of Biblical studies at public universities should incorporate views that arise from social sciences to investigate how power is solidified through textual interpretations. I use the term 'power' to refer to personal advantages and material privileges that are gained at the expense of others. On this, I will raise three areas of investigation.

Firstly, views from gender studies can be used to investigate how the Bible is used to solidify patriarchal cultural practices. For example, how the Old Testament patriarchal narratives and the story of Hanna who prayed for a male child or Jesus who singled out 12 male disciples, seem to support African culture's preference of male children. In using cultural studies, the focus is not on how the African culture and the biblical world compliment each other, but instead the focus will be on how the Bible is used as ideology to support patriarchal cultural practices. Feminist biblical scholars such as Mercy Oduyoye (2001:55), Musimbi Kanyoro (2002:34), Musa Dube (2000:20) and Madipoane Masenya have commented on the way the Bible is used to support patriarchal structures. 
Secondly, power is also political. With this in mind, the scholars at the departments of Biblical Studies at universities should critique how the Bible is used to maintain structures of power. As Segovia (1998a) says, biblical scholars should investigate how religious rhetoric is used by those in power to perpetuate oppression. Hence, there is need to:

deconstruct western moorings and monopoly over issues of biblical hermeneutics. Effort should be put to expose and deconstruct dominate hegemonic worldview in biblical interpretation seen in labels such as believers/pagan, true God and false gods, religious and idolatrous. (p. 3)

Scholars of Biblical Studies should investigate how popular culture that celebrates power, competition and victory seem to permeate and find expression through catchphrases such as 'the mighty Jesus' 'powerful Jesus' and 'victorious Jesus'. This shows how popular culture is central in our subjective interpretation of religious images. In a blog post, a Sheffield university scholar, James Crossly (2012) illustrates this by saying that:

A long-standing and dominant feature of the quest for the historical Jesus is the idea of Jesus as Great Man. This form of individualism works in harmony with a dominant capitalist understanding of causality, particularly the importance of a freely acting autonomous individual who functions as a historical mover not only avoids a more totalized view of history and explanations of historical change, but implicitly justifies the normality of capitalism as part of the mysterious or eternal laws of nature. (p. 1)

The idea is that religious motifs can be used to justify economic principles such as capitalism.

Connected to the above, is the issue that religious studies should investigate how economic disparity or injustice is sustained through religious interpretations. The study of religion should critically investigate the extent to which present forms of Christianity address issues of justice and oppression, and to what extent they deconstruct embedded social hierarchies. Does religion implicitly perpetuate master and slave, rich and poor categories? Church hymnal songs that say 'This world is not my home', 'Take all the riches and give me Jesus', should be investigated in terms of how they condone poverty and exploitation and how the songs postpone people's happiness into heaven. Biblical studies should also be critical of traditional Christian terms such as conversion, repentance, confirmation, which seem to perpetuate labels such as a sinful African people's world versus a righteous White people's West by asking the question: When African people repent of their sins, what sins, and conversion into what?

Finally, adopting cultural studies as an approach to biblical studies will tap views from social sciences such as migration studies to investigate how religious practices such as speaking in tongues are implicitly a form of migration or a quest for a better place. Speaking in tongues expresses a desire to relocate to another space (Dube 2012:245). There is a desire by people who speak in tongues to be identified with the other world. Hence, the speaking of another language is a culmination of the psychological desire whereby the person speaks with a different language, a clear proof of change, space and identity. In relocating to another space, this psychological desire is a veiled protest against the political leaders. As protest, the believers use religious language through which the enemy is coded as Satan and they reclaim justice and equality robbed from them by the oppressors.

\section{Conclusion}

In this article, I battle with insurmountable issues which are difficult to fit into a brief study. The study began by observing that Biblical Studies departments at public universities show a low student turnout and that the public has a low regard of biblically-oriented subjects. The study noted that despite the low reception of the Bible at public universities, its place in the community is secure and vibrant. Hence, the focus of the study is not about giving a prescription on how the communities should interpret the Bible. Instead, it attempts to bridge the gap between the academy and the communities. The study noted that the continuous use of Western methods in the academy silences African scholars and readers from raising their own issues and questions. Western methods tend to confine the meaning of the Bible to the past, thus distancing the academy from the social realities facing the people. In addition, despite the use of contextual methods, these tend to look at contextual similarities between the world of the Bible and the contemporary world.

Faced with this reality, the article proposes the use of cultural studies in teaching and researching biblical studies at public universities. In my view, this is not a new approach, but its advantage is that it brings various elements together instead of isolated applications for instance, a feminist or postcolonial approach. A multidisciplinary approach utilises several and multiple perspectives to interpret the Bible. The intended benefit is that it weans biblical studies from focusing on the past and context, only to further raise questions regarding how the Bible is used in popular culture and how it is used to sustain certain ideologies and power. In my view, such an approach will make universities produce graduates who are able to use their knowledge of the Bible to critically engage with events around them. Using cultural studies as a theoretical tool, the knowledge of biblical studies will become a critical asset for graduates in Biblical Studies.

\section{Acknowledgements Competing interests}

The author declares that he has no financial or personal relationship(s) which may have inappropriately influenced him in writing this article.

\section{References}

Baker, C., 2008, Cultural studies: Theory and practice, Sage, London.

Crossley, J., n.d., 'Jesus the GREAT Man', in Sheffield Bible Studies, viewed 01 September 2012, from http://sheffieldbiblicalstudies.wordpress.com/2012/05/21/jesus-thegreat-man/ 
Dube, M., 2000, Postcolonial feminist interpretation of the Bible, Charles Press, St Louis. Dube, Z., 2012, 'Speaking in tongues as emigration: A socio-psychological understanding of tongue speaking using migration theory', In Scriptura 110(2), 238-249.

Foucault, M., 1980, Power and knowledge: Selected interviews and other writings 1972-1977, Vintage Books, New York. PMid:6246137

Kabasela, F., 1997, 'Jesus as ancestor and elder brother', in R.J. Scheiter (ed.), Faces of Jesus in Africa, pp. 123-124, Orbis Books, New York.

Kanyoro, M., 2002, Introduction to feminist cultural hermeneutics: A key to African women's liberation theology, Continuum, London.

Maluleke, T.S., 2000, 'Bible among the African Christians: A missiological perspective', in T. Okure (ed.), To cast fire upon the earth: Bible and mission collaborating in today's multicultural global context, pp. 87-102, Cluster Publications, Pietermaritzburg.

Masenya, M., 2004, 'Teaching Western-oriented Old Testament Studies to African students: An exercise in wisdom or in folly', Old Testament Essays 17(2), 455-469.
Mofokeng, T., 1988, 'Black Christian, the Bible and liberation', Journal of Black Theology 2, 34-42.

Oduyoye, M.A., 2001, Introducing African woman's theology, Sheffield Academic Press, Sheffield.

Segovia, F. F., 1998a, 'Introduction: pedagogical discourse and practices in contemporary biblical criticism: Towards a contextual biblical pedagogy', in F.F. Segovia \& M.A Tolbert (eds.), Teaching the Bible: The discourse and politics of biblical pedagogy, pp. 1-31, Orbis Books, Maryknoll.

Segovia, F.F., 1998b, 'Pedagogical discourse and practices in cultural studies: Towards a contextual biblical pedagogy', in F.F. Segovia \& M.A. Tolbert (eds.), Teaching the Bible: The discourse and politics of biblical pedagogy, pp. 118-136, Orbis Books, Maryknoll.

West, G.O., 1993, Contextual Bible study, Cluster Publications, Pietermaritzburg.

West, G.O., 2000, 'Mapping African biblical interpretation: A tentative sketch', in G. West \& M. Dube (eds.), The Bible in Africa, pp. 29-53, Brill, Leiden. 